\title{
Corrosion aspect of dental implants-An overview and literature review
}

\author{
Anuja Agarwal, Amit Tyagi, Anshuman Ahuja, Nishant Kumar*, Nayana De, Himanshu Bhutani \\ Department of Oral and Maxillofacial Surgery ITS Dental College, Hospital and Research Centre, Knowledge Park III, Greater Noi- \\ da, India \\ Email: *anujagoel@its.edu.in
}

Received 20 November 2013; revised 27 December 2013; accepted 4 January 2014

Copyright (C) 2014 Anuja Agarwal et al. This is an open access article distributed under the Creative Commons Attribution License, which permits unrestricted use, distribution, and reproduction in any medium, provided the original work is properly cited. In accordance of the Creative Commons Attribution License all Copyrights (C) 2014 are reserved for SCIRP and the owner of the intellectual property Anuja Agarwal et al. All Copyright (C) 2014 are guarded by law and by SCIRP as a guardian.

\section{ABSTRACT}

The use of metals and their alloys in restorative and implant dentistry dates back to centuries. Titanium (Ti) is one of the most widely used biomaterial for medical implants because of its excellent mechanical properties and exceptional biocompatibility. The good biocompatibility of $\mathrm{Ti}$ is related to the thin oxide layer formed on $\mathrm{Ti}$ surface. $\mathrm{TiO}_{2}$ is inactive with the surrounding biological environment and quite compatible with living tissues. However, $\mathrm{TiO}_{2}$ layer can be destroyed during movements between implant and bone tissue under loading condition. The localized destruction causes corrosion of the implant, thus, weakening it; and can induce the leak of small metallic particles or ions into living tissues. This article highlights a review of the various aspects of corrosion and biocompatibility of dental titanium implants as well as suprastructures, and the methods to prevent it.

\section{KEYWORDS}

Implants; Corrosion; Titanium

\section{INTRODUCTION}

Implant dentistry is the second oldest discipline in dentistry after oral surgery. Root form implants have been used for thousands of years. 4000 years ago, the ancient Chinese used carved bamboo pegs, tapped into the bone, to replace lost teeth. 2000 years ago the ancient Egyptians used similarly shaped pegs made of precious metals. Some Egyptian mummies were found to have transplanted human teeth, and in other instances, teeth made of ivory [1].

\footnotetext{
"Corresponding author.
}

Titanium and titanium alloys are commonly used as dental implant materials. The process of integration of titanium with bone has been termed as "osseointegration" by Branemark [2]. The electrical properties and electrical stimulation of bone have been shown to control its growth and healing and can enhance osseointegration $[3,4]$. The metallic nature of the materials used for implant applications and the corrosive environments found in the human body, in combination with the continuous and cyclic loads to which these implants are exposed, may lead to corrosion and its corresponding electrochemical products.

Presently, most of the commercially available implant systems are made of pure titanium (CP-Ti) or titanium alloy Ti-6Al-4V. Titanium and its alloys provide strength, rigidity, and ductility similar to those of other dental alloys. Whereas, pure titanium castings have mechanical properties similar to Type III and Type IV gold alloys, some titanium alloy castings, such as Ti-6Al-4V and Ti$15 \mathrm{~V}$ have properties closer to $\mathrm{Ni}-\mathrm{Cr}$ and $\mathrm{Co}-\mathrm{Cr}$ castings with the exception of lower modulus [5]. The high corrosion resistance of titanium is due to the formation of a dense and stable layer of titanium oxide on its surface. Titanium oxide is responsible for chemical stability in the human body [6-10]. This layer is formed quickly because of the reactivity of the titanium with oxygen, which originates several oxides, with $\mathrm{TiO}_{2}$ being the major oxide formed. The corrosion resistance level stands high when exposed to most of the mineral acids, even within rather harmful media, such as hydrochloric acid or sulfuric acid, resulting in extremely low corrosion under these conditions [11-14].

Fluoride ions are one of the few media that have the ability to provide a corrosive effect to a titanium surface. When titanium is exposed to fluoride, its oxide layer is damaged, and titanium is then easily degraded. This is 
due to the incorporation of fluoride ions in the oxide layer, considerably decreasing its protective properties [15-17].

\section{ELECTRICAL SIGNALS INBONE-IMPLANT INTERFACE}

Both biopotentials and injury potentials are found in bone. Biopotentials in bone are classified into two subgroups, due in part to the complexity of bone structure: strain-related potentials (SRP) and biopotentials.

SRPs include the piezoelectric behavior (i.e., electric potential in response to applied forces) of bone due to the structure and bipolar charge of collagen, and streaming potentials associated with the flow of fluid and ions through porous bone. Mechanical forces have been shown to direct the process of bone remodeling [18-21]. Accordingly, areas of bone under stress tend to grow, and those areas under nomechanical load tend to be resorbed. This is believed to be a result of the physical stress alteration and biochemical activation of particular bone cells [22]. As a parallel event, however, areas of bone that are under mechanical load generate a more negative polarity than areas under smaller or no loads [23-25].

In children, fractured long bones tend to overgrow with respect to their counterparts and there is an increase in apoptosis in the growth plate [26]. Interestingly, both the healing site and growth plate tend to have a more negative potential compared with that of the nearby intact tissue. During development, the growth plate has a negative potential, while the growth plate of a mature individual tends to have a neutral voltage.

\section{TYPES OF CORROSION}

The most common types of corrosion found in metallic materials used for implant applications are galvanic, fretting, and pitting/crevice corrosion, as well as environmentally induced cracking (Figure 1).

Galvanic corrosion occurs with direct contact of two dissimilar metals in an electrolytic solution. Galvanic corrosionis not common in dental implant applications because of the presence of only one component, the dental screw, and the insulating nature of the protective passive layer that forms on the surface (Figure 2).

Fretting corrosion is caused by the repeated micromotion or friction of a metal component against another material that causes mechanical wear and breaks up the passivating layer on the contact surface of the metallic device. Fretting could also be an issue in total hip replacements, where it could generate wear debris and ions from friction between joint and socket. Recent studies have shown that fretting and oxide disruption at the surface of load-bearing implants can cause corrosion current densities to increase and generate open-circuit potentials in excess of $-500 \mathrm{mV}$ [27].

\section{CLINICAL RELEVANCE OF CORROSION}

Corrosion of metallic implants, a topic extensively dis-

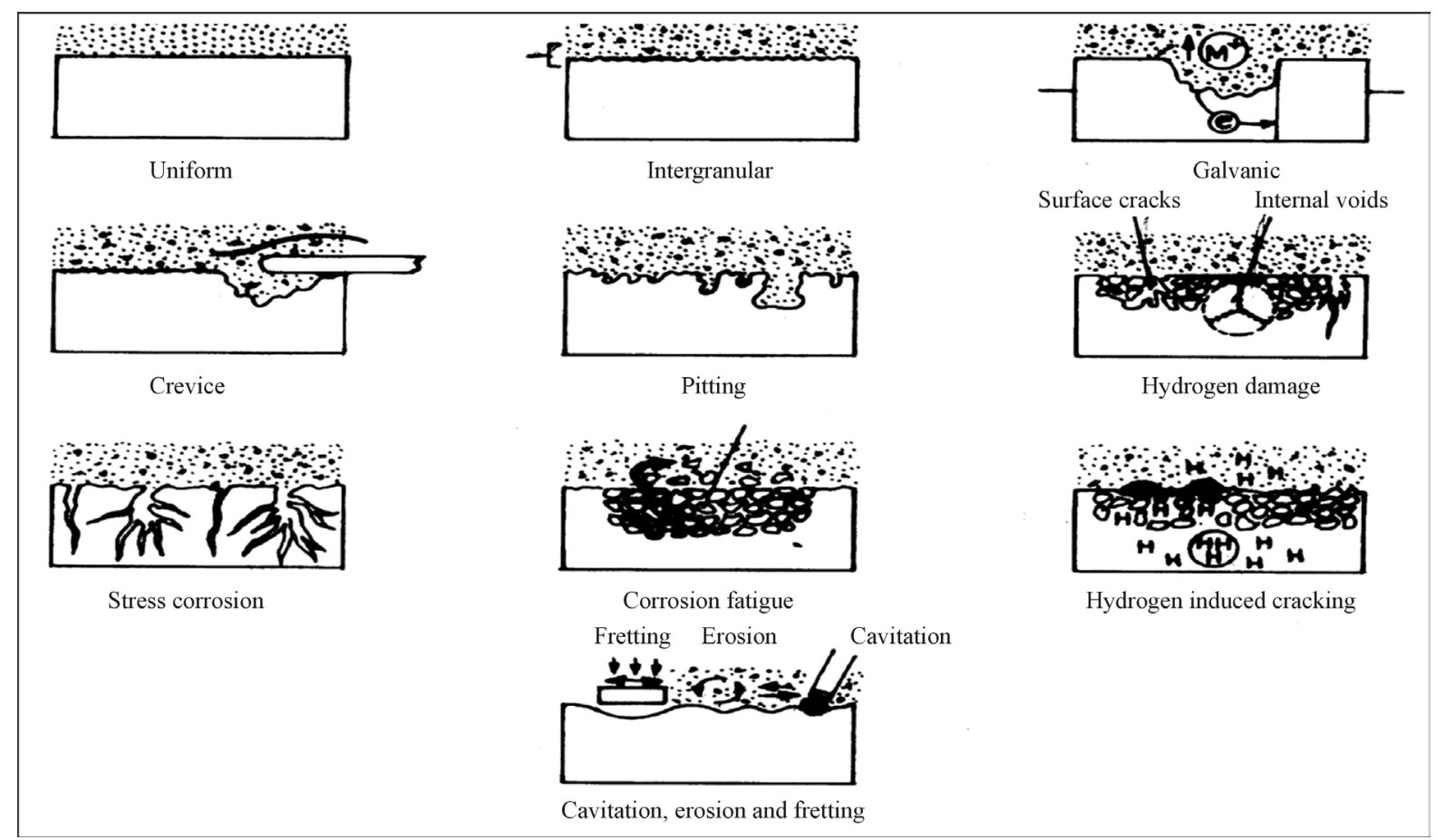

Figure 1. Diagrammatic summary of various types of corrosion. 


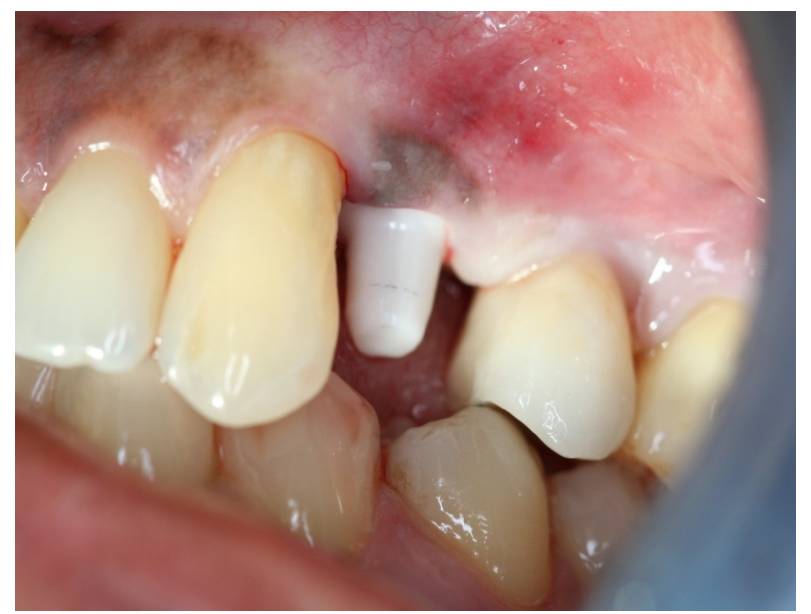

Figure 2. Corrosion in relation to upper first premolar.

cussed inorthopedic literature, may jeopardize the mechanical stability of the implant and the integrity of the surrounding tissue [28]. Implant failure in the form of aseptic loosening, or osteolysis, may result from metal release in the form of wear debris or electrochemical products generated during corrosion events. Metal ions such as $\mathrm{Ti}^{4+}, \mathrm{Co}^{2+}$, and $\mathrm{Al}^{3+}$ have been shown to decrease DNA synthesis, mitochondrial dehydrogenase activity, mineralization, and mRNA expression of alkaline phosphatase.

\section{HOW TO PREVENT CORROSION}

Ti dental implants are generally surface modified to reduce corrosion, improve osseointegration and increase the biocompatibility. To achieve this, surface treatments, such as surface machining, sandblasting, acid etching, electro polishing, anodic oxidation, plasma-spraying and Biocompatible/biodegradable coatings are performed to improve the quality and quantity of the bone-implant interface of titanium-based implants. Laser processing also is now being used in implant applications to produce a high degree of purity with enough roughness for good osseointegration $[29,30]$. Yue et al. used the excimer laser to modify the surface of the Ti-6Al-4V alloy to improve its corrosion resistance and there was a seven fold increase in the corrosion resistance.

Richard et al. observed that corrosion resistance and fretting wear of $\mathrm{Cp}$ Ti increased several fold when coated with nano $\mathrm{Al}_{2} \mathrm{O}_{3}-\mathrm{TiO}_{2}$ [31-33]. In addition to the above, nanoceramic HAP coatings are used to enhance the osseointegration. Nanostructured graded metalloceramic coatings have also been tried to achieve better adhesion between the metal and ceramic coatings and thus nanoceramic coatings are gradually receiving greater attention.

Ceramics are another class of materials which have high biocompatibility and enhanced corrosion resistance. They are widely used today for total hip replacement, heart valves, dental implants and restorations, bone fillers and scaffolds for tissue engineering, but ceramics are brittle, have high elastic modulus and can fracture as they posses low plasticity.

\section{DISCUSSION}

In spite of recent innovative metallurgical and technological advances and remarkable progress in the design and development of surgical and dental materials, failures do occur. One of the reasons for these failures can be corrosion of dental implants. The most favorable suprastructure/implant couple is the one which is capable of resisting the most extreme conditions that could possibly be encountered in the mouth. The choice of the materials used for the implant as well as implant borne suprastructures become crucial, and can be made by way of evaluating their galvanic corrosion behaviors.

Recently, titanium dioxide $\left(\mathrm{TiO}_{2}\right)$ was classified as possibly carcinogenic to human beings at the International Agency for Research on Cancer (IARC). The electrical implications of corrosion and its effect on the surrounding tissue may be an important key to this puzzle, but such effects still remain unclear. Corrosion events generate electrical currents due to electron transfer from ions in the solution to the metallic surface where reactions are occurring. These abnormal currents, and coupled electrical potentials, are directly related to the cyclic loads applied to the implant [27].

However, a fundamental understanding of the consequences of abnormal electrical signals on the growth and development of cells and tissues is required for the design of appropriate solutions and adequate treatment for affected individuals.

\section{REFERENCES}

[1] Misch, C.E. (2007) Contemporary implant dentistry. Mosby Elsevier, St. Louis, 26.

[2] Branemark, P.I., Hansson, B.O., Adell, R., Breine, U., Lindstrom, J., Halloeno, O., et al. (1997) Osseointegrated implants in the treatment of the edentulous jaw: Experience from a 10 year period. Scandinavian Journal of Plastic and Reconstructive Surgery and Hand Surgery. Supplementum, 16, 1-132.

[3] Steinemann, S.G. (1998) Titanium-The material of choice? Periodontology, 17, 7-21. http://dx.doi.org/10.1111/j.1600-0757.1998.tb00119.x

[4] Massaro, C., Rotolo, P., de Riccardis, F., et al. (2002) Comparative investigation of the surface properties of commercial titanium dental implants: Part I. Chemical composition. Journal of Materials Science: Materials in Medicine, 13, 535-548. 
http://dx.doi.org/10.1023/A:1015170625506

[5] Chaturvedi, T.P. (2009) An overview of the corrosion aspect of dental implants (titanium and its alloys). Indian Journal of Dental Research, 20, 91-98.

http://dx.doi.org/10.4103/0970-9290.49068

[6] O’Brien, W.J. (1978) Materials used in implantology. In O’Brien, W.J. and Ryge, G., Eds., Dental Materials and Their Selection, 2nd Edition, Vol. 1.

[7] Cochran, G.V., Pawluk, R.J. and Bassett, C.A. (1967) Stress generated electric potentials in mandible and teeth. Archives of Oral Biology, 12, 917-920. http://dx.doi.org/10.1016/0003-9969(67)90117-3

[8] Fathi, M.H., Salehi, M., Saatchi, A., et al. (2003) In vitro corrosion behavior of bioceramic, metallic and bioceramic-metallic coated stainlesssteel dental implants. Dental Materials, 19, 188-198. http://dx.doi.org/10.1016/S0109-5641(02)00029-5

[9] Kasemo, B. and Lausmaa, J. (1998) Biomaterial and implant surfaces: A surface science approach. International Journal of Oral \& Maxillofacial Implants, 3, 247-259.

[10] Aziz-Kerrzo, M., Conroy, R.G., Fenelon, A.M., et al. (2001) Electrochemical studies on the stability and corrosion resistance of titanium-based implant materials. Biomaterials, 22, 1531-1539.

http://dx.doi.org/10.1016/S0142-9612(00)00309-4

[11] Huang, H.H. (2002) Effects of fluoride concentration and elastic tensile strain on the corrosion resistance of commercially pure titanium. Biomaterials, 23, 59-63. http://dx.doi.org/10.1016/S0142-9612(01)00079-5

[12] Toumelin-Chemla, F., Rouellet, F. and Burdairon, G. (1996) Corrosive properties of fluoride containing odontologic gels against titanium. Journal of Dentistry, 24, 109-115. http://dx.doi.org/10.1016/0300-5712(95)00033-X

[13] Vargas, E., Baier, R. and Meyer, A. (1992) Reduce corrosion of cp Ti and Ti-6Al-4V alloy endosseous dental implant after glow discharge treatment: A preliminary report. International Journal of Oral \& Maxillofacial Implants, 7, 338-344.

[14] Donachie, M.J. (1987) Introduction. In Donachie, M. J., Ed., Titanium: A Technical Guide. ASM, Metals Park, 9-19.

[15] Barjj, A. (1976) EDS titanium. In James, W.J. and Straumanis, M.E., Eds., Encyclopedia of Electrochemistry of the Elements, Vol. 5, Dekker, New York, 305-395.

[16] Strietzel, R., Hösch, A., Kalbfleisch, H., et al. (1998) In vitro corrosion of titanium. Biomaterials, 19, 1495-1499. http://dx.doi.org/10.1016/S0142-9612(98)00065-9

[17] Koike, M. and Fujii, H. (2001) The corrosion resistance of pure titanium in organic acids. Biomaterials, 22, 29312936. http://dx.doi.org/10.1016/S0142-9612(01)00040-0

[18] Reclaru, L. and Meyer, J.M. (1998) Effects of fluoride on titanium and otherdental alloys in dentistry. Biomaterials, 19, 85-92. http://dx.doi.org/10.1016/S0142-9612(97)00179-8

[19] Ferrier, J., Ross, S.M., Kanehisa, J. and Aubin, J.E. (1986) Osteoclasts and osteoblasts migrate in opposite directions in response to a constant electricalfield. Journal of Cellular Physiology, 129, 283-288.

http://dx.doi.org/10.1002/jcp.1041290303

[20] Levin, M. (2007) Large-scale biophysics: Ion flows and regeneration. Trends in Cell Biology, 17, 261-270. http://dx.doi.org/10.1016/j.tcb.2007.04.007

[21] Burr, D.B., Robling, A.G. and Turner, C.H. (2002) Effects of biomechanical stress on bones in animals. Bone, 30, 781-786. http://dx.doi.org/10.1016/S8756-3282(02)00707-X

[22] Duncan, R.L. and Turner, C.H. (1995) Mechano-transduction and the functional response of bone to mechanical strain. Calcified Tissue International, 57, 344-358. http://dx.doi.org/10.1007/BF00302070

[23] Fukada, E. and Yasuda, I. (1957) On the piezoelectric effect of bone. Journal of the Physical Society of Japan, 12, 1158-1162. http://dx.doi.org/10.1143/JPSJ.12.1158

[24] Black, J. (1986) Electrical stimulation: Its role in growth, repair, and remodeling of the musculoskeletal system. Praeger Publishers, New York.

[25] Black, J., Baranowski, T.J. and Brighton, C.T. (1984) Electrochemical aspects of DC stimulation of osteogenesis. Bioelectrochemistry and Bioenergetics, 12, 323-327. http://dx.doi.org/10.1016/0302-4598(84)87012-9

[26] Gaber, S., Fischerauer, E.E., Frohlich, E., Janezic, G., Amerstorfer, F. and Weinberg, A.M. (2009) Chondrocyte apoptosis enhanced at the growth plate: Aphyseal response to a diaphyseal fracture. Cell and Tissue Research, 335, 539-549. http://dx.doi.org/10.1007/s00441-008-0735-0

[27] Gilbert, J.L., Mehta, M. and Pinder, B. (2009) Fretting crevice corrosion of stainless steel stem-Co-Cr femoral head connections: Comparisons of materials, initial moisture, and offset length. Journal of Biomedical Materials Research Part B: Applied Biomaterials, 88, 162-173.

[28] Jacobs, J.J., Urban, R.M., Hallab, N.J., Skipor, A.K., Fischer, A. and Wimmer, M.A. (2009) Metal-on-metal bearing surfaces. Journal of the American Academy of Orthopaedic Surgeons, 17, 69-76.

[29] Kumar, S., Narayanan, T.S., Raman, G.S.S. and Seshadri, S.K. (2010) Microstructural and electrochemical characterization. Materials Chemistry and Physics, 119, 337346. http://dx.doi.org/10.1016/j.matchemphys.2009.09.007

[30] Geetha, M., Durgalakshmi, D. and Asokamani, R. (2010) Biomedical implants: Corrosion and its prevention-A review. Recent Patents on Corrosion Science, 2, 40-54. http://dx.doi.org/10.2174/1877610801002010040

[31] Jiang, P., He, X.L., Li, X.X., Yu, L.G. and Wang, H.M. (2000) Wear resistance of a laser surface alloyed Ti-6Al$4 \mathrm{~V}$ alloy. Surface and Coatings Technology, 130, 24-32. http://dx.doi.org/10.1016/S0257-8972(00)00680-0

[32] Richard, C., Kowandy, C., Landoulsi, J., Geetha, M. and Ramasawmy, H. (2010) Corrosion and wear behavior of thermally sprayed nano ceramic coatings on commercially pure Titanium and Ti-13Nb-13Zr. International Journal of Refractory Metals and Hard Materials, 28, 115123. http://dx.doi.org/10.1016/j.ijrmhm.2009.08.006 
[33] Baan, R., Straif, K., Grosse, Y., Secretan, W., El Ghissassi, F., Cogliano, V., et al. (2006) Carcinogenicity of carbon black, titanium dioxide, and talc. Lancet Oncology,
7, 295-296.

http://dx.doi.org/10.1016/S1470-2045(06)70651-9 